\title{
MINERAL NUTRITION OF CRISPHEAD LETTUCE GROWN IN A HYDROPONIC SYSTEM WITH BRACKISH WATER ${ }^{1}$
}

\author{
HAMMADY RAMALHO E SOARES ${ }^{2 *}$, ÊNIO FARIAS DE FRANÇA E SILVA ${ }^{3}$, GERÔNIMO FERREIRA DA \\ SILVA $^{3}$, RAQUELE MENDES DE LIRA ${ }^{2}$, RAPHAELA REVORÊDO BEZERRA ${ }^{2}$
}

\begin{abstract}
Water availability in the Brazilian semiarid is restricted and often the only water source available has high salt concentrations. Hydroponics allows using these waters for production of various crops, including vegetables, however, the water salinity can cause nutritional disorders. Thus, two experiments were conducted in a greenhouse at the Department of Agricultural Engineering of the Federal Rural University of Pernambuco, to evaluate the effects of salinity on the mineral nutrition of crisphead lettuce, cultivar Taina, in a hydroponic system (Nutrient Film Technique), using brackish water in the nutrient solution, which was prepared by adding $\mathrm{NaCl}$ to the local water $\left(0.2 \mathrm{dS} \mathrm{m}^{-1}\right)$. A randomized blocks experimental design was used in both experiments. The treatments consisted of water of different salinity levels $(0.2,1.2,2.2,3.2,4.2$ and $5.2 \mathrm{dS}$ $\mathrm{m}^{-1}$ ) with four replications, totaling 24 plots for each experiment. The water added to compensate for the waterdepth loss due to evapotranspiration (WCET) was the brackish water of each treatment in Experiment I and the local water without modifications in Experiment II. The increase in the salinity of the water used for the nutrient solution preparation reduced the foliar phosphorus and potassium contents and increased the chloride and sodium contents, regardless of the WCET. Foliar nitrogen, calcium, magnesium and sulfur contents were not affected by increasing the water salinity used for the nutrient solution preparation.
\end{abstract}

Keywords: Lactuca sativa L. Salinity. Horticulture.

\section{NUTRIÇÃO MINERAL DE ALFACE AMERICANA EM CULTIVO HIDROPÔNICO COM ÁGUAS SALOBRAS}

Resumo - No semiárido brasileiro a disponibilidade hídrica é restrita e muitas vezes a única fonte de água disponível possui altas concentrações de sais. A hidroponia permite o uso dessas águas para a produção de diversas culturas, dentre elas as hortaliças, entretanto, a salinidade pode ocasionar distúrbios nutricionais. Diante disso, foram conduzidos dois experimentos em ambiente protegido no Departamento de Engenharia Agrícola da Universidade Federal Rural de Pernambuco, objetivando-se avaliar os efeitos da salinidade sobre a nutrição mineral da alface americana cv. Tainá em sistema hidropônico Nutrient Film Technique (NFT), utilizando águas salobras no preparo da solução nutritiva, sendo essas águas obtidas pela adição de $\mathrm{NaCl}$ a água de abastecimento local $\left(0,2 \mathrm{dS} \mathrm{m}^{-1}\right)$, e a reposição da lâmina evapotranspirada realizada usando a respectiva água salobra utilizada no preparo da solução no Experimento I e, com água de abastecimento local no Experimento II. Para ambos os experimentos o delineamento experimental utilizado foi o de blocos ao acaso com seis tratamentos $\left(0,2 ; 1,2 ; 2,2 ; 3,2 ; 4,2\right.$ e $\left.5,2 \mathrm{dS} \mathrm{m}^{-1}\right)$, e quatro repetições, totalizando 24 parcelas experimentais para cada experimento. $\mathrm{O}$ aumento da salinidade da água utilizada no preparo da solução nutritiva, independente da estratégia de reposição da lâmina evapotranspirada, proporcionou redução nos teores foliares de fósforo e potássio e aumento nos teores de cloreto e sódio. Os teores foliares de nitrogênio, cálcio, magnésio e enxofre não foram influenciados pelo aumento da salinidade da água utilizada no preparo da solução nutritiva.

Palavras-chave: Lactuca sativa L. Salinidade. Horticultura.

\footnotetext{
*Corresponding author

${ }^{1}$ Received for publication in 06/12/2014; accepted in 05/05/2016.

Paper extracted from the Master's Dissertation of the first author.

${ }^{2}$ Postgraduate students at Agricultural Engineering, Universidade Federal Rural de Pernambuco, Recife, PE, Brazil; hresoares@hotmail.com, raquele.lira@hotmail.com, raphaelarevoredo38@gmail.com.

${ }^{3}$ Department of Agricultural Engineering, Universidade Federal Rural de Pernambuco, Recife, PE, Brazil; effsilva@uol.com.br, geronimo.silva@ufrpe.br.
} 


\section{INTRODUTION}

Salinity in the root environment can affect the agricultural production, limiting the plant growth and development, and thus restricting land use and production (PORCEL; AROCA; RUIZ-LOZANO, 2012).

The effects of salts are more noticeable in semiarid regions due to the combination of an intense evaporation and little precipitation, and are shown by the high osmotic pressure and toxic effects of some ions such as $\mathrm{Na}^{+}$and $\mathrm{Cl}^{-}$, causing various physiological disorders for crops (OLIVEIRA et al., 2009). According to Silva (2014) salinity can also cause ionic antagonisms due to the excess in nutrients, leading to a low plant growth and development because the nutritional imbalance caused by a high ionic concentration in the nutrient solution and inhibition of absorption of other cations by the sodium.

High salinity can cause nutritional disorders, especially to sensitive plants. According to López et al. (2014), the concentrations of ions $\mathrm{Na}^{+}$and $\mathrm{Cl}^{-}$ may exceed the concentrations of other essential nutrients and result in disorders for the absorption of $\mathrm{Ca}^{2+}$ and $\mathrm{K}^{+}$by modifying the root absorption of these nutrients and their translocation in the plant.

The supplying of good quality water for irrigation is not always possible in many regions, especially in arid and semiarid regions. Water with high salt contents can salt the soil used for conventional agriculture, increasing the concentration of various ions in the plant and compromising the production (KALAVROUZIOTIS; KOUKOULAKIS; MEHRA, 2010).

Hydroponic systems increase the plant tolerance to salinity compared to conventional farming, because the absence of the matric potential (SOARES et al., 2007). The nutrient and water absorptions is more efficient in hydroponics and allows the use of saline waters for irrigation (SANTOS JÚNIOR, 2013).

Studies in the literature confirm that the use of brackish water is related to the crop tolerance to salt stress (SOARES et al., 2007; PAULUS et al., 2010; DIAS et al., 2011a; DIAS et al., 2011b; OLIVEIRA et al., 2011), and most of them were performed with lettuce crops (Lactuca sativa L.), which stands out in Brazil as the most produced vegetable in the hydroponic system Nutrient Film Technique (NFT) (PAULUS et al., 2012).

Researches on mitigating the saline effects in crops and quantification of nutrients in saline conditions through technologies that enable the use of brackish water are needed, especially for the semiarid region, in which the use of brackish water is often the only option for producers.

The objective of this work was to evaluate the salinity effects on mineral nutrition of the crisphead lettuce, cultivar Taina, in a hydroponic system NFT, using a brackish water for the nutrient solution preparation, in two experiments using water added to compensate for the water-depth loss due to evapotranspiration (WCET) of different salinity levels.

\section{MATERIAL AND METHODS}

The experiments were conducted in a greenhouse of the Department of Agricultural Engineering at the Federal Rural University of Pernambuco (UFRPE), $\left(08^{\circ} 01^{\prime} 05^{\prime \prime} \mathrm{S}, 34^{\circ} 05^{\prime} 48^{\prime \prime} \mathrm{W}\right.$ and altitude of $6,5 \mathrm{~m}$ ), in February (Experiment I) and June (Experiment II), 2013.

The temperature and relative humidity data were measured with a psychrometer installed inside the greenhouse. The Experiment I had air temperatures between $27.5^{\circ} \mathrm{C}$ and $34^{\circ} \mathrm{C}$ and relative air humidity between $70 \%$ and $83 \%$. The Experiment II had air temperatures between $25^{\circ} \mathrm{C}$ and $32^{\circ} \mathrm{C}$ and relative air humidity between $67 \%$ and $80 \%$.

A randomized blocks experimental design was used in both experiments, with six salinity levels of the water used for the nutrient solution preparation (0.2 [T1], 1.2 [T2], 2.2 [T3], 3.2 [T4], 4.2 [T5] and 5.2 [T6] dS m$~^{-1}$ ), obtained by adding $\mathrm{NaCl}$ (P.A.; purity of $99.5 \%)$ to the local water $\left(0.2 \mathrm{dS} \mathrm{m}^{-1}\right)$, and four replications, totaling 24 experimental plots for each experiment.

In Experiment I, the most simplistic use of brackish water by farmers was simulated, with no additional management to the usual hydroponics with non-brackish water, but with the brackish water of each treatment as WCET.

In Experiment II, treatments were maintained with constant salinity throughout the crop cycle, in order to assess the crop tolerance and simulate a situation in which the technified farmer can control the electrical conductivity of the solution (ECsol) by using a WCET of good quality.

$\mathrm{NaCl}$ was not added to the treatment $\mathrm{T} 1$ (control; $0.2 \mathrm{dS} \mathrm{m}^{-1}$ ). The hydroponic nutrient solution used was prepared according to the methodology of Furlani (1998).

Nutrients were not added to solution during the crops cycles. The electrical conductivity and $\mathrm{pH}$ evaluations were performed every two days in order to verify the nutrient solution characteristics during the crop cycle, however, these data were not subjected to statistical analysis.

The crisphead lettuce cultivar used was the Taina, which was seeded in phenolic foam of $2.0 \mathrm{x}$ $2.0 \times 2.0 \mathrm{~cm}$, treated with potassium hydroxide $\mathrm{KOH}$ $(0.01 \mathrm{~N})$, using two seeds per quadrant, totaling 240 plants for each experiment. The plates with the phenolic foam were kept in the dark for about 24 hours for seed germination and taken to the plant nursery, where they received the nutrient solution 
Furlani (1998) diluted to 50\%, which was exchanged for a solution with $100 \%$ of the ionic strength after a week. Fifteen days after sowing (DAS), the seedlings of the two experiments were transplanted to the growing tubes.

The growing tubes of the hydroponic system NFT was spaced $0.30 \mathrm{~m}$, arranged in groups of four, installed at $0.80 \mathrm{~m}$ from the ground, with slope of $5 \%$ and spacing between plants of $0.25 \mathrm{~m}$.

The waters were prepared in a 240-liter tank, the ECsol and $\mathrm{pH}$ were measured, and macro and micronutrients were used for the nutrient solution preparation. One liter of a concentrate (1:1000) solution was prepared for the micronutrients, as well as for the iron, which had an individual chelated solution concentrate $(1: 1000)$ due to its instability in the nutrient solution. The $\mathrm{pH}$ and ECsol readings were measured again after homogenization.

The fertilizers used for the nutrient solution preparation were calcium nitrate, potassium nitrate, monoammonium phosphate (MAP), magnesium sulfate, copper sulfate, zinc sulfate, manganese sulfate, boric acid, sodium molybdate and Fe-EDTA13\% (Furlani, 1998).

The hydroponic system of the plant nursery and experiments was controlled by a mechanical timer with irrigation programmed for every 15 minutes. The irrigation programming had 15-minute intervals from $5: 00 \mathrm{~h}$ to $18: 00 \mathrm{~h}$ when the experiments were installed and every hour from this time, with an irrigation of 15 minutes, since at night time the evaporation is low. Cultural practices to control pests and diseases were not needed during the experiments.

The crisphead lettuce was harvested at 21 (Experiments I) and 30 (Experiments II) days after transplanting (DAT). Subsequently, the shoots were separated from the roots and subjected to a temperature of $70^{\circ} \mathrm{C}$ in a forced air circulation oven until constant mass. The dry material was ground and stored in labeled plastic containers for later quantification of $\mathrm{N}, \mathrm{Na}, \mathrm{K}, \mathrm{P}, \mathrm{S}, \mathrm{Ca}, \mathrm{Mg}$ and $\mathrm{Cl}$

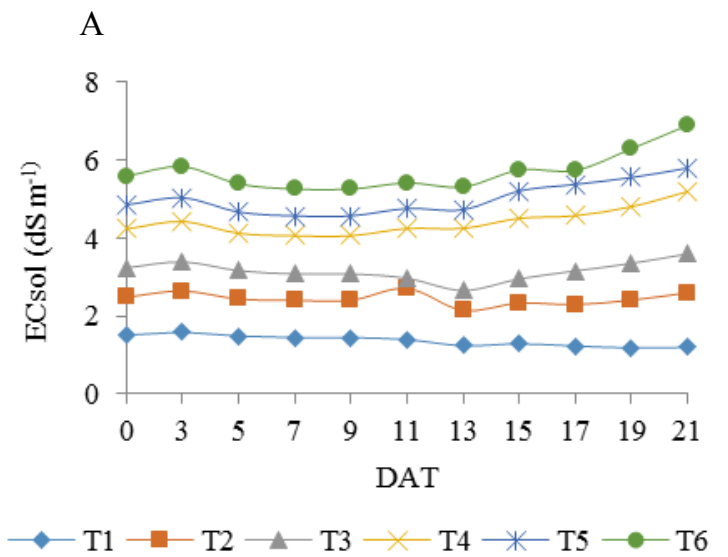

contents.

The mineral elements in the plant tissue was analyzed through nitro-perchloric digestion $\left(\mathrm{HNO}_{3}+\right.$ $\mathrm{HClO}_{4}$ ) at ratio of $3: 1 \mathrm{v} / \mathrm{v}$, which is used for analyze most nutrients in plants, except for $\mathrm{N}$ and $\mathrm{Cl}$. Total nitrogen was evaluated by the Kjeldahl method; sodium and potassium by the flame photometry method; phosphorus by the molybdo-vanadate colorimetric method; sulfur by the turbidimetric method of barium sulfate; chloride by the Mohr's method; and calcium and magnesium by atomic absorption spectrophotometry, following methodological procedures suggested by Bezerra Neto and Barreto (2011).

The data were subjected to analysis of variance by the $\mathrm{F}$ test and regression analysis using the software SISVAR 5.3, and the choice of models was based on the significance of the regression coefficients by the $t$ test, $\alpha$ of up to $5 \%$ probability, and the highest coefficient of determination $\left(\mathrm{R}^{2}\right)$.

\section{RESULTADS AND DISCUSSION}

The mean values of the nutritive solution electrical conductivity, found during the crisphead lettuce cycle is shown in Figure 1. An increase in ECsol in the T4 $\left(3.2 \mathrm{dS} \mathrm{m}^{-1}\right), \mathrm{T} 5\left(4.2 \mathrm{dS} \mathrm{m}^{-1}\right)$ and T6 $\left(5.2 \mathrm{dS} \mathrm{m}^{-1}\right)$ treatments over time were found in Experiment I (Figure 1A), due to the accumulation of salts because the increase in the salinity levels of the water used to prepare the nutrient solution and the lower absorption of nutrients in these treatments. On the other hand, the treatment $\mathrm{T} 1$, in which the nutrient solution was prepared with non-brackish water $\left(0.2 \mathrm{dS} \mathrm{m}^{-1}\right)$, a decrease in ECsol over time was observed, due to the WCET was performed with non-brackish water, thus, a decreased in water salinity with consequent reduction of the solution electrical conductivity occurred as the plants consumed the nutrients required for its development.

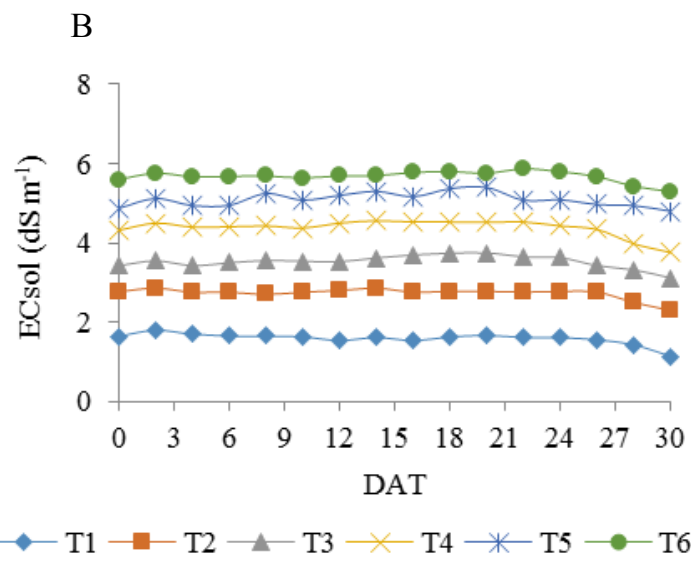

Figure 1. Mean values of the nutritional solution electrical conductivity (ECsol) in Experiments I (A) and II (B). 
These results confirm those found by Soares et al. (2010), who evaluated the effects of sweet and brackish water combination in the production of hydroponic lettuce and found that the ECsol of the treatments remained relatively constant during the experiment because the WCET had good quality.

The nutrient solution electrical conductivity showed a small decrease over the cycle in Experiment II, the opposite was observed in the Experiment I, however, this reduction was more pronounced at the cycle end (Figure 1B), because the WCET had good quality.

The $\mathrm{pH}$ of the nutrient solution in Experiment I (Figure 2A) and Experiment II (Figure 2B) remained in a range in which most of the nutrients are adequately available to plants, since the $\mathrm{pH}$

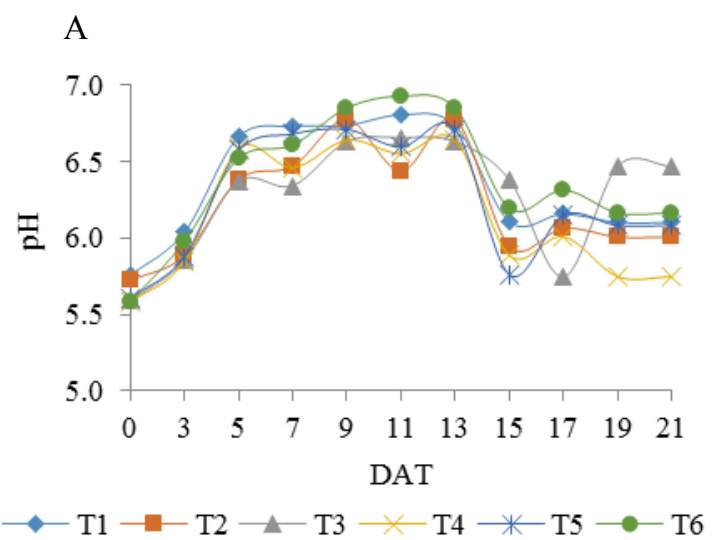

ranging from 5.5 to 6.5 does not influence negatively most cultures (MACIEL et al. 2012). According to Furlani et al. (1999), pH ranging from 4.5 to 7.5 does not compromise the plant growth in hydroponic systems, however, under acidic condition (below 4.0) may compromise the integrity of the cell membrane. Moreover, in alkalinity situations (above 8.0) symptoms of nutrient deficiency, such as phosphorus, may occur.

The $\mathrm{pH}$ of the nutrient solution had an increase and then a reduction in both experiments (Figure 2), possibly due to the intake of nutrients by the plants. The tendency to alkalinity in the experiments was due to the imbalance of cations and anions in the nutrient solution because the inherent difference in the absorption of these ions by plants.

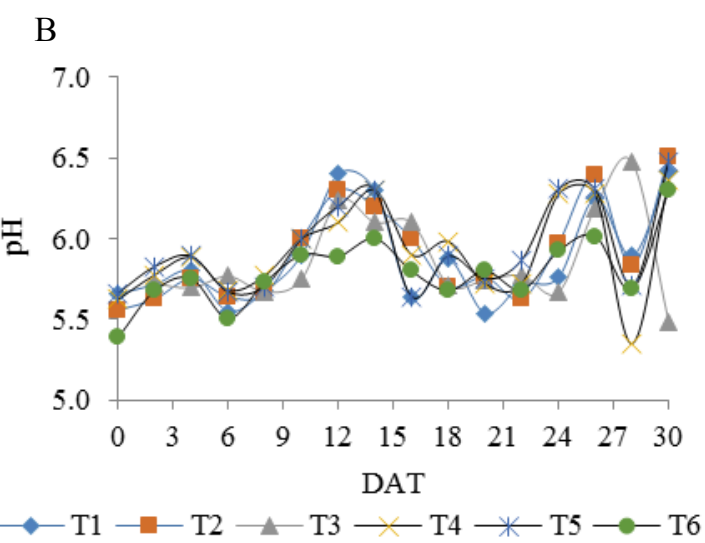

Figure 2. $\mathrm{pH}$ of the nutrient solution during the crop cycle in Experiments I (2A) and II (2B).

According to Marschner (2012), pH variations of nutrient solutions are due to the unbalanced absorption of ions by plants.

An elevation of $\mathrm{pH}$ in the medium occurs when the roots absorb more anions than cations, because the roots release $\mathrm{OH}^{-}$in the solution. On the other hand, when the anion absorption is less than the cation absorption, the roots release $\mathrm{H}^{+}$in the nutrient solution resulting in a reduced $\mathrm{pH}$.

The nitrogen absorption by the roots greatly contribute to variations in the $\mathrm{pH}$ of the nutrient solution, since the intake of nitrogen ions by the plant is high (Figure 2A and 2B). The absorption of $\mathrm{NH}_{4}^{+}$by the roots releases $\mathrm{H}^{+}$, decreasing the $\mathrm{pH}$, causing excessive acidity of the medium, however, the $\mathrm{pH}$ of the nutrient solution can increase as soon as the $\mathrm{NH}_{4}{ }^{+}$has been absorbed and the absorption of $\mathrm{NO}_{3}{ }^{-}$is greater than the $\mathrm{NH}_{4}{ }^{+}$absorption. The $\mathrm{NO}_{3}{ }^{-}$ absorption remove anions of the nutrient solution, resulting in a progressive increase of $\mathrm{pH}$. The increase and decrease of $\mathrm{pH}$ found in Experiments I and II possibly occurred due to these characteristics of the nitrogen absorption.

The foliar concentrations of phosphorus, potassium, sodium and chloride in the plants from both experiments were significantly affected by the salinity of the nutrient solution (Table 1), however, the nitrogen, calcium, magnesium and sulfur concentrations were not affected by the increase in the water salinity. Similar results were found by Paulus et al. (2012), who evaluated 5 salinity levels $\left(2.0 ; 3.3 ; 5.8 ; 8.3\right.$ e $\left.10.4 \mathrm{dS} \mathrm{m}^{-1}\right)$, obtained by adding $\mathrm{NaCl}$ to the nutrient solution, in the first cycle cultivation, and found that the nitrogen and sulfur concentrations were not affected by high salinity, however, the calcium, magnesium and potassium concentrations decreased with increasing salinity of the nutrient solution.

Regression analysis showed that the increase in the nutrient solution salinity stimulated the accumulation of sodium (Figure 3A) and inhibited $\mathrm{K}$ (Figure 3B) in the leaves in both experiments. The brackish WCET provided an increase of $39.4 \%$ in $\mathrm{Na}+$ concentration in the shoots of the plants per unit increased in the electrical conductivity of the water $(\mathrm{ECw})$ used for the nutrient solution preparation (Figure 3A). On the other hand, when the WCET used had good quality $(0.2 \mathrm{dS} \mathrm{m}-1)$, the $\mathrm{Na}$ concentration in the plants also increased, but to a lesser extent $(23.2 \%$ per unit increase in $\mathrm{ECw})$ because the salinity increase due to ion accumulation that were not absorbed by the plants. 
Table 1. Analysis of variance of the nitrogen $(\mathrm{N})$, phosphorus $(\mathrm{P})$, potassium $(\mathrm{K})$, calcium $(\mathrm{Ca})$, magnesium $(\mathrm{Mg})$, sulfur $(\mathrm{S})$, sodium $(\mathrm{Na})$ and chloride $(\mathrm{Cl})$ contents in the shoot of crisphead lettuces, depending on different water salinity levels $(\mathrm{ECw})$ used for the nutrient solution preparation in the Experiments I and II.

\begin{tabular}{|c|c|c|c|c|c|c|c|c|}
\hline \multirow{2}{*}{$\begin{array}{l}\text { Source of } \\
\text { variation }\end{array}$} & \multicolumn{8}{|c|}{ F test - Experiment I } \\
\hline & $\mathrm{N}$ & $\mathrm{P}$ & $\mathrm{K}$ & $\mathrm{Ca}$ & $\mathrm{Mg}$ & $\mathrm{S}$ & $\mathrm{Na}$ & $\mathrm{Cl}$ \\
\hline $\mathrm{ECw}$ & $0.57^{\mathrm{ns}}$ & $88.7^{* *}$ & $26.7^{* *}$ & $1.51^{\mathrm{ns}}$ & $0.34^{\mathrm{ns}}$ & $1.35^{\mathrm{ns}}$ & $158.9^{* *}$ & $52.02^{* *}$ \\
\hline \multirow[t]{2}{*}{ CV (\%) } & 3.74 & 6.22 & 6.89 & 3.99 & 3.10 & 5.91 & 5.70 & 9.30 \\
\hline & \multicolumn{8}{|c|}{ F test - Experiment II } \\
\hline $\mathrm{ECW}$ & $0.46^{\mathrm{ns}}$ & $79.9^{* *}$ & $18.27^{* *}$ & $0.41^{\mathrm{ns}}$ & $0.41^{\mathrm{ns}}$ & $0.21^{\mathrm{ns}}$ & $77.7^{* *}$ & $28.1^{* *}$ \\
\hline CV $(\%)$ & 9.7 & 5.5 & 8.5 & 14.1 & 1.7 & 8.2 & 6.3 & 9.3 \\
\hline
\end{tabular}

${ }^{* *}=$ significant at $1 \%$ probability; ${ }^{\mathrm{ns}}=$ not significant. $\mathrm{CV}=$ coefficient of variation.
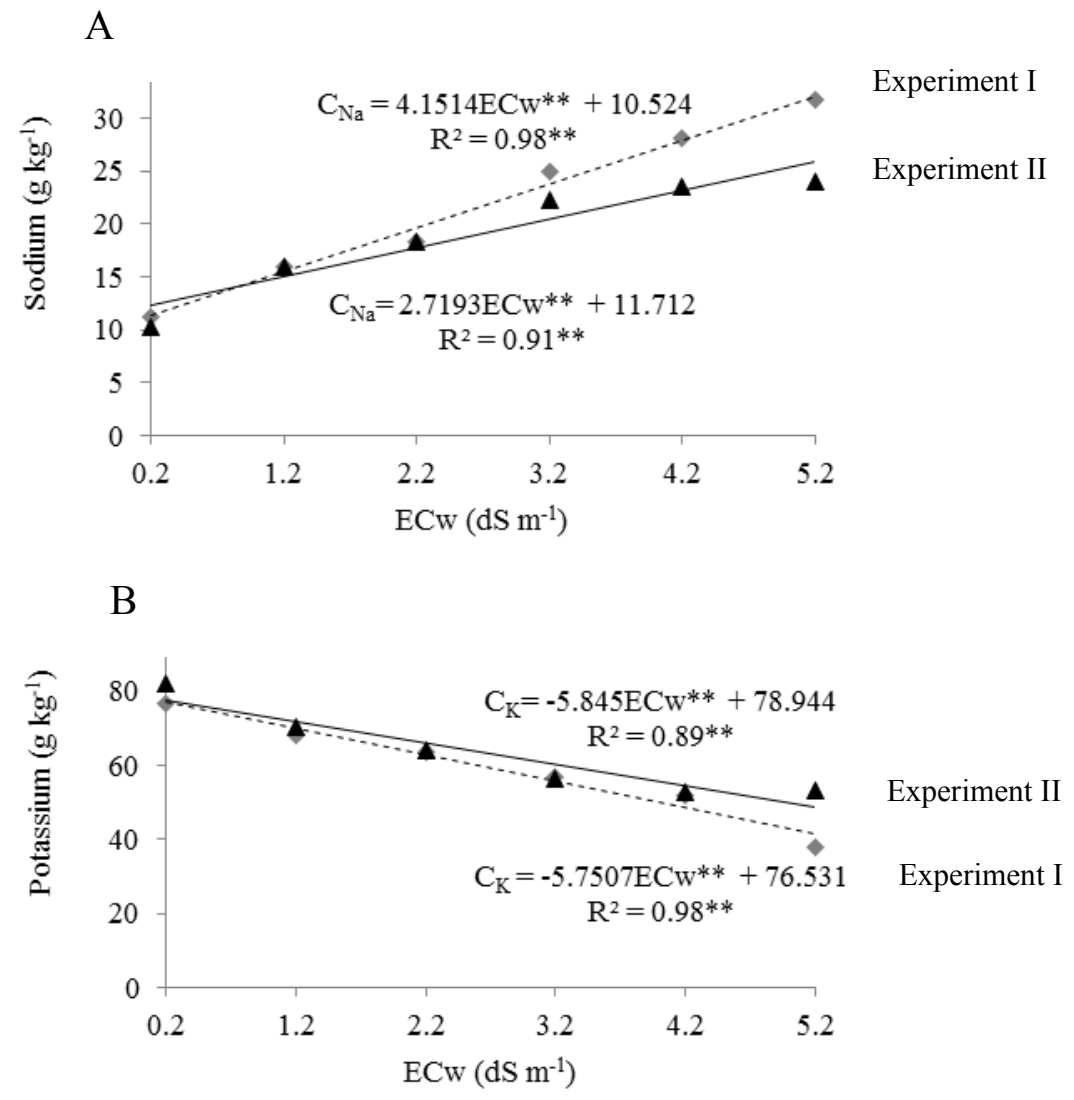

Figure 3. Sodium (A) and potassium (B) concentration in the shoot of crisphead lettuces, cultivar Taina, depending on the electrical conductivity of the water $(\mathrm{ECw})$ used for the nutrient solution preparation in Experiments I and II.

The increase in sodium content in the shoots, regardless of the WCET used, is a response to the source of salts used for the nutrient solution preparation (sodium chloride), which increased the salt concentrations in the nutrient solution, possibly influencing the absorption and accumulation of sodium in the shoots. According to Furlani (1999), a greater absorption of nutrients by plants in hydroponics occurs with high concentrations of these nutrients in the nutrient solution.

The sodium concentration in the plants were similar to those found by Bosco et al. (2009), who found sodium concentrations around $30 \mathrm{~g} \mathrm{~kg}^{-1}$ of the dry matter, with an electrical conductivity of the nutritive solution of $5.0 \mathrm{dS} \mathrm{m}^{-1}$.
The increase from $0.2 \mathrm{dS} \mathrm{m}^{-1}$ to $5.2 \mathrm{dS} \mathrm{m}^{-1}$ in the salinity of the water used for the nutrient solution preparation caused a decrease in $\mathrm{K}$ content in the shoot of 7.51 (Experiment I) and 7.40\% (Experiment I) (Figure 3B), depending on the unit increase in EC of the brackish WCET (Experiment I) and WCET of good quality (Experiment II). These results show disorders for the ionic homeostasis by the increase in $\mathrm{Na}$ concentration and decreasing in $\mathrm{K}$ concentration (WILLADINO; CAMARA, 2010).

The inverse correlation between $\mathrm{K}$ and $\mathrm{Na}$ accumulation in the leaf tissue of the plants, found in both experiments, were related to the competition of these ions for same absorption site and transport in the plasma membrane. Thus, according to the ion 
antagonism between these elements, the $\mathrm{K}$ concentrations in leaf tissue decreased by increasing concentrations of $\mathrm{Na}$.

Paulus et al. (2012) evaluated nutrient extractions in hydroponic lettuce with brackish waters and also found reduced absorption of $\mathrm{K}$ (51\%) with increasing salinity (2.0 to $\left.10.4 \mathrm{dS} \mathrm{m}^{-1}\right)$, results that were different from those found in the present work, possibly due to the salinity range adopted, cultivar, and climatic conditions. Gondim et al. (2010) found a decrease in absorption of $\mathrm{K}$ in lettuce, cultivar Brasil-303, with increasing salinity of the nutrient solution, assessing electrical conductivities between 0.5 and $4.0 \mathrm{dS} \mathrm{m}^{-1}$, and that the highest salt concentration $\left(\begin{array}{llll}4.0 & \mathrm{dS} & \mathrm{m}^{-1}\end{array}\right)$ contributed to a greater reduction in $\mathrm{K}$ content in the leaves.

Several studies have shown a decrease in $\mathrm{K}$ concentration due to the ionic antagonism with $\mathrm{Na}$. Paulus et al. (2012) evaluated the mineral composition of lettuce, cultivar Veronica, and concluded that the $\mathrm{K}$ concentration decreased with increasing salinity.

The $\mathrm{P}$ concentration in plants decreased with increasing electrical conductivity of the water used for the nutritive solution preparation, regardless of the WCET used (Figure 4). P concentration decreased by $10.4 \%$ due the increase in $\mathrm{ECw}$ using brackish WCET and 9.5\% with WCET of good quality.

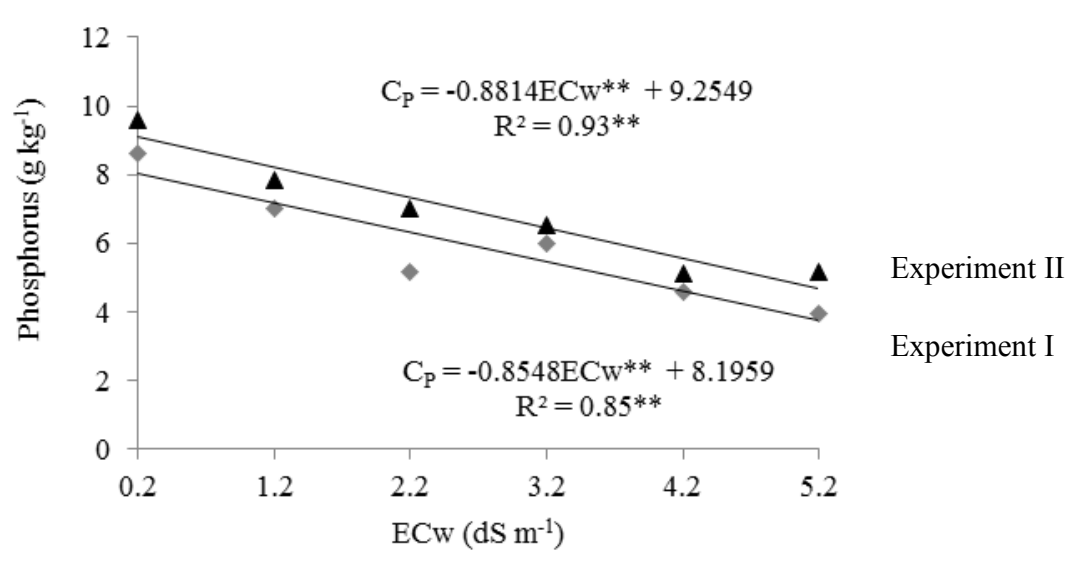

Figure 4. Phosphorus concentration in the shoot of crisphead lettuce, cultivar Taina, depending on the electrical conductivity of the water $(\mathrm{ECw})$ used for the nutrient solution preparation in Experiments I and II.

The phosphorus concentration in the control treatment, estimated by regression model was 8.02 (Experiments I) and 9.1 (Experiments II) $\mathrm{g} \mathrm{kg}^{-1}$ of the dry matter (Figure 4). This result was similar to those found by Filgueiras, Takahashi and Beninni (2002), who evaluated the hydroponic lettuce, cultivar Veronica, with different electrical conductivities, and found $\mathrm{P}$ concentration of $7.4 \mathrm{~g} \mathrm{~kg}^{-1}$ in the shoots of the plants in control treatment.

The more saline treatments at the end of the cycle $\left(5.2 \mathrm{dS} \mathrm{m}^{-1}\right)$ in the experiments showed that the $\mathrm{P}$ concentration was $3.74 \mathrm{~g} \mathrm{~kg}^{-1}$ of the dry matter when the WCET was a brackish water (Experiment I), and $4.67 \mathrm{~g} \mathrm{~kg}^{-1}$ of the dry matter when the WCET had good quality (Experiment II). Malavolta, Vitti and Oliveira (1997) evaluated lettuces of 20 DAT and found $\mathrm{P}$ concentration of $3.5 \mathrm{~g} \mathrm{~kg}^{-1}$ of the dry matter, thus, the $\mathrm{P}$ absorption in Experiments I and II were similar to those found by these authors.

According to Bezerra Neto and Barreto (2011), the $\mathrm{P}$ concentration in plant tissues may vary from 1 to $15 \mathrm{~g} \mathrm{~kg}^{-1}$ of the dry matter. Although the percentage of $\mathrm{P}$ reduced during the experiments, its concentration remained within the expected range and no deficiency symptoms were found in the plants.

The chloride content $(\mathrm{Cl})$ increased linearly in the plants of Experiment I and up to $3.6 \mathrm{dS} \mathrm{m}^{-1}$ in the plants of Experiment II with increasing salinity of the nutrient solution. The regression equation model that best fitted the data for Experiment I was the linear, and for Experiment II was the quadratic. The maximum $\mathrm{Cl}$ concentration in the shoot of the plants was found in Experiment II $\left(44.5 \mathrm{~g} \mathrm{~kg}^{-1}\right.$ of the dry matter) with ECw of $3.6 \mathrm{dS} \mathrm{m}^{-1}$, decreasing from this $\mathrm{ECW}$ (Figure 5), showing a possible defense mechanism of the plant to salt stress. An increase of $30.45 \%$ in $\mathrm{Cl}$ concentration per unit increase of $\mathrm{ECW}$ was found in the Experiment I, in which the WCET had good quality. According to Marschner (2012), chloride contents above $2.5 \mathrm{~g} \mathrm{~kg}^{-1}$ can cause toxicity in sensitive plants. 


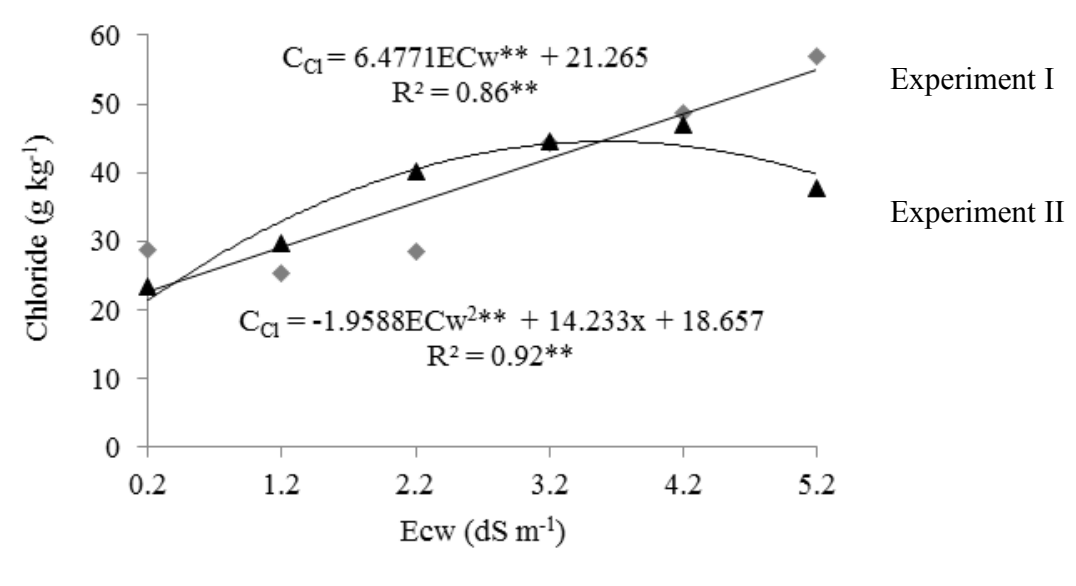

Figure 5. Chloride concentration in shoots of crisphead lettuce, cultivar Taina, depending on the electrical conductivity of the water $(\mathrm{CEw})$ used for the nutrient solution preparation in Experiments I and II.

The high chloride concentrations in the nutrient solution may decrease the absorption of nitrogen, sulfur and phosphorus anions, due to the antagonism between them and the chloride (MARSCHNER, 2012).

No significant effects on the nitrogen and sulfur concentrations were found in the experiments (Table 1), however, reductions in $\mathrm{P}$ concentrations in Experiments I and II (Figure 5) can be explained by the increase of chloride concentration in the plants.

The nitrogen, phosphorus, potassium, calcium, magnesium concentrations $(30-50(\mathrm{~N}), 4-7$ (P), $50-80(\mathrm{~K}), 15-25(\mathrm{Ca})$ and $4-6(\mathrm{Mg}) \mathrm{g} \mathrm{kg}^{-1}$ of the dry matter) in the shoots of the lettuce, with both WCET, were within the range indicated by Silva (1999), and similar to the results found by Trani and Raij (1997), and the sulfur concentration (2-5 g kg-1 of the dry matter) were within the range indicated by Silva Júnior and Soprano (1997).

The concentration of nitrogen, calcium, magnesium and sulfur ions in the shoot remained constant and the salinity levels evaluated caused no nutritional disorder for macronutrients, but increased
$\mathrm{Na}$ and $\mathrm{Cl}$ contents in the leaves of the crisphead lettuce cropped in a hydroponic system (NFT) using brackish water with electrical conductivity of up to $5.2 \mathrm{dS} \mathrm{m}^{-1}(\mathrm{NaCl})$.

The increase in $\mathrm{Na}$ and $\mathrm{Cl}$ contents in the leaves (Figure 6) due to the absorption that increased their concentration in the shoots occurred because these toxic ions were not removed by the plants, resulting in toxicity, as observed by the symptom in the plants of the more saline treatments $\left(5.2 \mathrm{dS} \mathrm{m}^{-1}\right)$.

Nevertheless, the use of brackish water for hydroponic production of crisphead lettuce, in the conditions of this experiment, shows potential for reducing socioeconomic impacts, considering that replication of this methodology may improve this effect in producing regions of lettuce that have this types of water.

Regarding the environment, this proposal avoids the effluents to be released in watercourses, inferring a conservationist profile, and the possibility of using this water sources instead of waters of better quality emphasizes the efficiency of use of water resources.

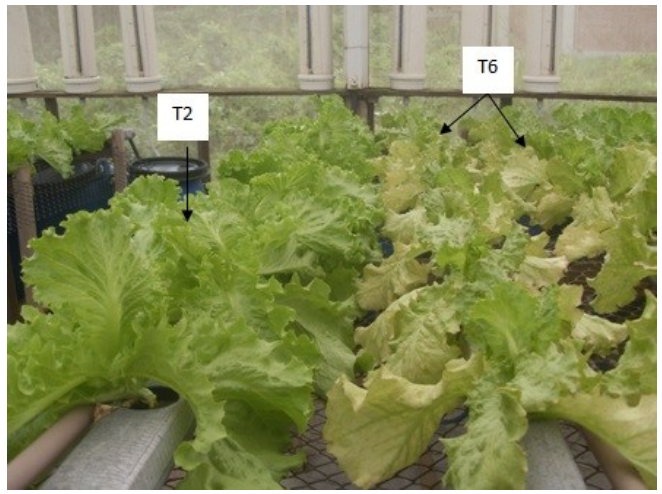

Figure 6. Symptoms of accumulation of $\mathrm{Na}^{+}$and $\mathrm{Cl}^{-}$ions in the shoot of crisphead lettuces.

\section{CONCLUSIONS}

The increase in the salinity of the water used for the nutrient solution preparation, regardless of the water added to compensate for the water-depth loss due to evapotranspiration, reduced the phosphorus and potassium contents and increased chloride and sodium contents in the leaves.

The use of brackish for the nutrient solution preparation had no effect on the absorption of the 
nutrients nitrogen, calcium, magnesium and sulfur.

\section{ACKNOWLEDGEMENTS}

The authors thank the Research Support Foundation of the State of Pernambuco (FACEPE), CNPq and CAPES for scholarships and the INCTSal/CNPq for supporting this scientific research.

\section{REFERENCES}

BEZERRA NETO, E.; BARRETO, L. P. Análises químicas e bioquímicas em plantas. 1. ed. Recife, PE: Editora Universitária, 2011. 267 p.

BOSCO, M, R. O. et al. Influência do estresse salino na composição mineral da berinjela. Revista Ciência Agronômica, Fortaleza, v. 40, n. 2, p. 157-164, 2009.

DIAS, N. S. et al. Resposta de cultivares de alface à salinidade da solução nutritiva com rejeito salino em hidroponia. Revista Brasileira de Engenharia Agrícola e Ambiental, Campina Grande, v. 15, n. 10, p. 991-995, 2011b.

DIAS, N. S. et al. Uso de rejeito da dessalinização na solução nutritiva da alface, cultivada em fibra de coco. Revista Ceres, Viçosa, v. 58, n. 5, p. 632-637, 2011 a.

FILGUEIRAS, R. C.; TAKAHASHI, H. W.; BENINNI, E. R. Y. Produção de alface hidropônico em diferentes condutividades elétricas. Semina: Ciências Agrárias, Londrina, v. 23, n. 2, p. 157-164, 2002.

FURLANI, P. R. Instruções para o cultivo de hortaliças de folhas pela técnica de hidroponia NFT. 1.ed. Campinas: IAC, 1998. 30 p. (Boletim técnico, 168).

FURLANI, P. R. et al. Cultivo hidropônico de plantas. 1. ed. Campinas: IAC, 1999. 52 p. (Boletim técnico, 180).

FURLANI, P. R. Hydroponic vegetable production in Brazil. Acta Horticulturae, Wageningen, v. 2, n. 481, p. 777-778, 1999

GONDIM, A. R. O. et al. Condutividade elétrica na produção e nutrição de alface em sistema de cultivo hidropônico NFT. Bioscience Journal, Uberlândia, v. 26, n. 6, p. 894-904, 2010.

KALAVROUZIOTIS, I. K.; KOUKOULAKIS, P.
H.; MEHRA, A. Quantification of elemental interaction effects on Brussels sprouts under treated municipal wastewater. Desalination, Amsterdam, v. 254, n. 1-3, p. 6-11, 2010.

LÓPEZ, U. P. et al. Responses of nutrient dynamics in barley seedlings to the interaction of salinity and carbon dioxide enrichment. Environmental and Experimental Botany, Oxford, v. 99, n. 3, p. 86-99, 2014.

MACIEL, M. P. et al. Produção de girassol ornamental com uso de águas salobras em sistema hidropônico NFT. Revista Brasileira de Engenharia Agrícola e Ambiental, Campina Grande, v. 16, n. 2, p. 165-172, 2012.

MALAVOLTA, E.; VITTI, G. C.; OLIVEIRA, S. A. Avaliação do estado nutricional das plantas: princípios e aplicações. 2. ed. Piracicaba, SP: Potafos, 1997. 319 p.

MARSCHNER, P. Mineral nutrition of higher plants. 3. ed. London: Academic Press, 2011. 651 p.

OLIVEIRA, F. A. et al. Desempenho de cultivares de alface submetidas a diferentes níveis de salinidade da água de irrigação. Revista Brasileira de Engenharia Agrícola e Ambiental, Campina Grande, v. 15, n. 8, p. 771-777, 2011.

OLIVEIRA, F. A. et al. Tolerância de cultivares de algodoeiro herbáceo à salinidade da água de irrigação. Revista Brasileira de Oleaginosas e Fibrosas, Campina Grande, v. 13, n.3, p. 91-97, 2009.

PAULUS, D. et al. Produção e indicadores fisiológicos de alface sob hidroponia com água salina. Horticultura Brasileira, Brasília, v. 28, n. 1, p. 29-35, 2010.

PAULUS, D. et al. Crescimento, consumo hídrico e composição mineral de alface cultivada em hidroponia com águas salinas. Revista Ceres, Viçosa, v. 59, n. 1, p. 110-117, 2012.

PORCEL, R.; AROCA, R.; RUIZ-LOZANO, J. M. Salinity stress alleviation using arbuscular mycorrhizal fungi. A review. Agronomy for Sustainable Development, Granada, v. 32, n. 1, p. 181-200, 2012.

SANTOS JÚNIOR, et al. Efficiency of water use in sunflower grown in hydroponic system under saline stress. Revista Engenharia Agrícola, Campina Grande, v. 33, n. 4, p. 718-729, 2013.

SILVA, A, O. A fertirrigação e o processo de salinização de solos em ambiente protegido. Revista 
Nativa Pesquisas Agrárias e Ambientais, Sinop, v. 2, n. 3, p. 180-186, 2014.

SILVA, F. C. (Org.). Manual de análises químicas de solos, plantas e fertilizantes. Brasília, DF: Embrapa Comunicação para Transferência de Tecnologia, 1999. 370 p.

SILVA JÚNIOR, A. A.; SOPRANO, E. Caracterização de sintomas visuais de deficiências nutricionais em alface. Florianópolis, SC: EPAGRI, 1997. $319 \mathrm{p}$.

SOARES, T. M. et al. Produção de alface utilizando águas salinas em sistema hidropônico. Irriga, Botucatu, v. 12, n. 2, p. 235-248, 2007.

SOARES, T. M. et al. Combinação de águas doce e salobra para produção de alface hidropônica. Revista Brasileira de Engenharia Agrícola e Ambiental, Campina Grande, v. 14, n. 7, p. 705-714, 2010.

TRANI, P. E.; RAIJ, B. van. Hortaliças. In: Raij B. van. et al. (Ed.). Recomendações de adubação e calagem para o Estado de São Paulo. Campinas: Instituto Agronômico/Fundação IAC, 1997, cap. 18, p 157-163. (Boletim Técnico, 100).

WILLADINO, L.; CAMARA, T. R. Tolerância das plantas à salinidade: aspectos fisiológicos e bioquímicos. Revista Enciclopédia Biosfera, Goiânia, v. 6, n. 11, p. 2-23, 2010. 